\title{
Welcoming Happy Primary School
}

\section{Kinzang Wangchuk*}

Teacher, Laptsakha Primary School, Punakha, Bhutan

*Corresponding Author: Kinzang Wangchuk, Teacher, Laptsakha Primary School, Punakha, Bhutan.

To begin with, on the joyous occasion of Sherig Century Celebrations, I too would like to extend my Tashi Delek to everybody and would like to take this opportunity to share some of my feelings on Primary education in Bhutan and welcoming happy Primary school.

I feel deeply humbled for having given this opportunity despite my limited knowledge on the present primary education scenario, to speak a few lines about primary education and the architects of our primary education - our primary teachers. My write up is particularly focused on welcoming primary school teachers as they have the most crucial role to play in shaping our children's destiny, and of course, welcoming our children too. If our primary teachers are able to create the most appropriate platform for our young minds to flourish, we would have already built a secure future for them. Let's not forget His Majesty the fourth Druk Gyalpo's noble words, "The future of our nation lies in the hands of our children".

May I now outline some of the objectives:

- $\quad$ First and foremost is for welcoming our primary teachers and students to be part of this historic celebration and to applaud our teachers for their endeavor in providing the primary education to our children.

- To reflect upon the fact that a teaching profession is the noblest service to the country and a teacher has to dedicate himself/herself, heart and soul, in this work.

However, let's not forget that it will be the most rewarding ultimately:

- The concept of psychosocial ambience as applied to our contexts refers to the atmosphere, ambience, tone, or climate that prevails in our schools and has been one of the most important factors of determining how well our schools function. It is the psychological well being of our schools and therefore, these types of platforms where we talk and share our concerns with teachers and students could help boost the morale of our schools.
Received: May 11, 2021

Published: May 29, 2021

(C) All rights are reserved by Kinzang

Wangchuk.
- Teaching in primary schools is an important task to perform and it needs a high level of motivation on the part of teachers. A teacher, outwardly, appearing intelligent and competent may suffer from low motivation.

- Therefore, teachers' as well as the learners' motivation is essential for better learning outcomes.

- A quality teaching has very strong impact upon the academic performance of the students, especially, at primary level. The teacher helps in the educational, social and psychological growth of the child in a healthy and balanced way.

- We have all gathered here to remember that learning is not merely about intellectual growth of a child. We must cherish the human potentials to create a passion for learning. Let's also remember that a passion for teaching is not only to express enthusiasm but also to demonstrate our inner intention to educate a child.

- And let us all (teachers and students) work collaboratively and re-dedicate ourselves for the cause of primary education in our country.

Let's help our teachers:

- To be a good example

- To draw out "goodness" from within

- To impart knowledge

- To be a good facilitator

- To be a good leader

- To be a good classroom manager

- To create a conducive atmosphere

- To play all roles.

\section{Characteristics of a happy school}

- High expectations in terms of academic standards

- $\quad$ Caring teachers 
- $\quad$ Respectful relationship between different stakeholders - students, parents, teachers, principals, authorities, etc.

- Strong academic and instructional focus

- Regular assessment of individual students

- Non authoritarian principal and collaborative decision making practices in place.

Strong staff morale and work ethics:

- Absence of corporal punishment

- Conducive learning atmosphere.

A primary school is just like a patch of budding flowers. Like flowers, our students are all of different sizes and shapes, with all their similarities and differences. Are they red and alert, are they yellow and pensive, or are they lavender and loveable? Our students come to us with their individual personalities, and our schools, communities of teachers, staff, and other children also add our spin to produce what each will become.

We mould our classrooms and our school environment from our beliefs and customs, and each school has its own special personality. How do we determine what our school will be? It is up to all of us to contribute to our school communities in our own ways.

A happy school needs all the colors of the rainbow and more. We need red for excitement of learning new things, we have orange and yellow to represent our Bhutan flag and all of the traditions that our beloved culture bring to us. Green is the environment that we take care of and respect, and blue is the peace that we feel for a job well done. Indigo is for late evening when our homework is done and we find our rest to refresh us for the next day together. Violet is the early morning awakening and excitement that comes with the day ahead filled with enjoyment together.

The seven colors of the rainbow shine above for us through the sunny days and the rainy days and produce the beautiful and diverse flowers of our children. There is neither more pleasing nor more precious than the minds and hearts of each of our children.

Parents and teachers are the gardeners, the nurturers of the future of our country. We have our future leaders before us every day. Let the colors of the beautiful world around us delight our senses every day, and keep our schools the most colorful and the happiest school in the world guided by the philosophy GNH.

Well, it is said until the 1950s, the only formal education available to Bhutanese students was through Buddhist monasteries.

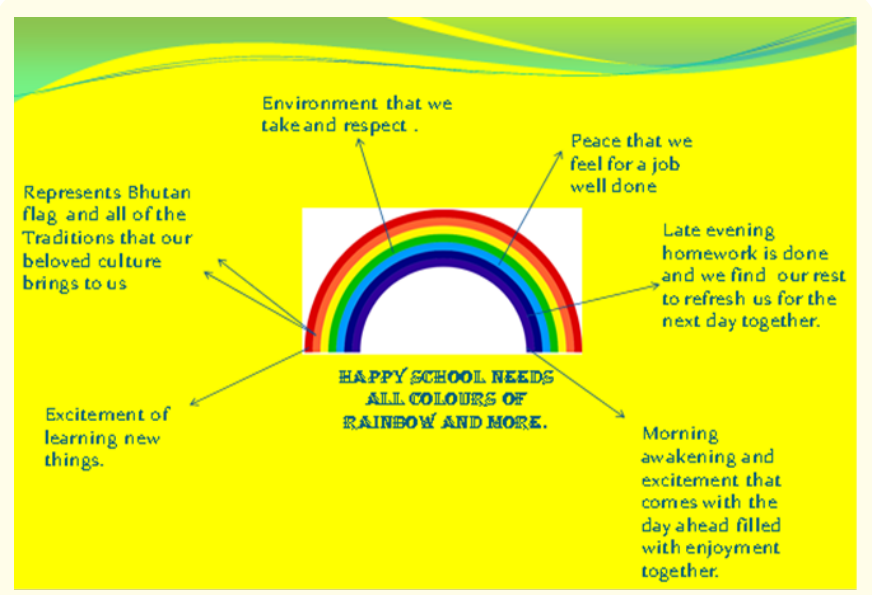

Figure 1

However, realizing the importance of modern education for a developing country like ours, our visionary leader and the father of modern Bhutan, His Majesty Jigme Dorji Wangchuk, had already embarked on a journey of modern education for Bhutan and therefore, by the late 1950s, there were several primary schools in our country, even though the enrollment was comparatively less. Nonetheless, a start had already been made and there was no looking back. Now, as we celebrate a hundred years of education in Bhutan, our country can boast of a total of as many as 606 schools and institutes in our country. Bhutan is now a proud achiever of her long time goal of Universal Primary Education.

Primary education, in our context, typically means the time period that primary school spans, from pre-primary to sixth grade, and it is a child's first step into academic learning, time to work or learn on one's own, as well as time to socialize and learn with one's peers. Children who effectively develop during their primary education will be emotionally and socially healthy.

Primary education is the most important step in a child's educational career. It is a crucial stage for a child's overall development and will shape the child into a learner, thinker and a social being. Therefore, to produce quality youth for our tomorrow, we must lay the foundation for the quality education they receive and it is the primary schools that can offer children a safe environment in which to grow, and provide children with skills and motivation that can help them cope with the challenges of the 21st century. It provides children with better chances to explore new ideas and to develop their individual skills and personality as well. 
Teaching has the reputation of being "the noblest of all professions," and our primary teachers remain testimony to that. They are truly the noblest of the professionals. On this solemn occasion, let's salute our heroes who are in every nook and corner of our country - from the frosty mountains of Gasa, to remote hamlets of Trongsa or Zhemgang, to rugged terrains of Trashiyangtse, to hot and sticky sub tropicals of Samtse or Sarpang-transforming our ugly ducklings and helping them soar into the vastness of the sky as beautiful swans. They are our primary school teachers, those who love children and are highly motivated regardless of where they work. It is, indeed, humbling to talk about teachers who work hard despite all odds.

Teaching in a primary school is not everybody's cup of tea, and reasons for it could be numerous and varied - it's either the school is extremely remote, the parents are too ignorant, or the school lacks materials to teach in creative, interesting ways. Despite all these hardships, our teachers in remote corners do know that the school is the children's second home and their teachers are secondary parents. Therefore, it sounds only prudent to acknowledge the importance of primary education.

To sum up, I would like to stress here that primary education should be given the highest priority because this is the children's stepping-stone for them to pursue higher goals. All wonderful opportunities are possible if primary education is not taken for granted. An old adage says "a journey of thousand miles begins with our first single step" and this to me, very much holds water.

Thus, the primary education that our children will be fulfilling will serve as the first step towards achieving their success. Sending a child to a primary school is the sole responsibility of the parents, but to make sure they get the requisite knowledge, skills and values is the responsibilities of our primary teachers.

And finally, my dear fellow teachers, we know that the world never pays you rich tributes in the form of awards and accolades. Nonetheless, to you, our dearest teachers, the architects of our children's destiny, we offer our solemn gratitude and reaffirm our dedication and support in your war against illiteracy and your mission to dispel the darkness of ignorance.

Volume 4 Issue 6 June 2021

(C) All rights are reserved by Kinzang Wangchuk. 